\title{
42. PALEOMAGNETISM OF THE VOLCANIC SEQUENCE IN HOLE 642E, ODP LEG 104, VØRING PLATEAU, AND CORRELATION WITH EARLY TERTIARY BASALTS IN THE NORTH ATLANTIC1
}

\author{
Günther Schönharting ${ }^{2}$ and Niels Abrahamsen ${ }^{3}$
}

\begin{abstract}
Paleomagnetic data from a 907-m thick volcanic sequence from Hole 642E on the Vøring Plateau, Norwegian Sea, are presented. NRM, susceptibility, Q-ratio, stable inclination, and polarity values were determined for 520 samples obtained from 118 flows, 7 dikes, and 12 volcaniclastic units. Declination values were also estimated from AF demagnetization analysis on suitable samples.

The magnetic polarity in the upper 778-m thick series of tholeitic lavas and sediments is reversed throughout while the polarity of the $136-\mathrm{m}$, more silicic lower series is interpreted to be predominantly normal with widespread reversed component overprint caused by dike intrusions. A strong contrast in magnetic properties between the upper and the lower series reflects the different primary and secondary petrological features of the series.

The reverse upper series is correlated with chron $24 \mathrm{r}$ of the magnetic polarity time scale, with an age of ca. $54 \mathrm{Ma}$. This timing matches well with other areas of the North Atlantic Volcanic Province and indicates a common age for the surge of voluminous volcanic activity before the onset of spreading. The inclination record of the upper series indicates an extremely fast rate of extrusion that possibly exceeds growth rates of lava piles like those in Iceland by an order of magnitude. The normal polarity of the lower series is correlated with chron 25 , indicating a hiatus between the two series. Comparison of paleolatitudes from the North Atlantic basalt province confirms a northward component of movement of some $15^{\circ}$ in the last 55 m.y. for the Vøring Plateau.
\end{abstract}

\section{INTRODUCTION}

During ODP Leg 104 five holes were drilled at Site 642 on the outer Vøring Plateau in the Norwegian Sea (Fig. 1). The deepest one, Hole $642 \mathrm{E}$, penetrated 138 volcanic flows, 7 dikes and a large number of intercalated volcaniclastics between 327 and $1229.4 \mathrm{~m}$ below the seafloor (mbsf). This volcanic sequence was divided into a tholeiitic upper series and a more silicic lower series (Eldholm, Thiede, Taylor, et al., 1987). Shipboard magnetic results showed a dramatic decrease in natural remanent magnetization (NRM) and magnetic susceptibility at the upper/ lower series boundary at 1087 mbsf. Polarity was predominantly reversed throughout the core, although there was some uncertainty about the lower series inclination due to rather unstable or erratic behavior of pilot samples during AF-cleaning.

On the ship a total of 307 cube samples were measured for NRM and AF-demagnetized in 5-mT peak AF fields. From these samples a further 89 samples were AF-demagnetized in peak fields up to $100 \mathrm{mT}$ and stable inclination and median destructive fields were determined. In many cases multicomponent remanence was recognized, and careful analysis of data, as well as many more measurements, were required to determine the primary magnetization. In addition, further analysis might help to estimate the mean declination values assuming that one of the magnetic components was of a viscous type acquired during the last magnetic chron (Brunhes).

A clear paleomagnetic record for the basalts, the dipping reflector series, and the underlying lower series is important with regard to correlation with results from other areas of the North

\footnotetext{
${ }^{1}$ Eldholm, O., Thiede, J., Taylor, E., et al., 1989. Proc. ODP, Sci. Results, 104: College Station, TX (Ocean Drilling Program).

2 Institute of General Geology, Copenhagen University, Østervoldgade 10, 1350 Copenhagen K, Denmark.

${ }^{3}$ Geophysical Laboratory, Geological Institute, Aarhus University, Finlandsgade 8, Aarhus N, Denmark.
}

Atlantic Volcanic Province (Larsen and Watts, 1985; Abrahamsen et al., 1984). Therefore a rather extensive sampling, over 500 new samples, was performed during Leg 104 to provide the material for shore-based laboratory studies.

For the upper volcanic series, these samples are sufficient for detailed investigation of the stable inclination record. For the lower series, the glassy nature of many of the flows and the degree of alteration made it more difficult to obtain a sufficient number of suitable samples. In view of extensive remagnetization effects by both chemical and thermal alteration and by dike intrusions, the stable inclination results are therefore more interpretive for the lower series than for the upper series.

Nevertheless, with the samples obtained we could attempt to contribute to the following problems: the correlation of polarity zones of the volcanic series with the magnetic polarity scale, reconstruction of paleolatitude and, perhaps, the duration of volcanic activity at Site 642 . These samples, together with other geophysical and geological information from the Vøring Plateau and other key areas of the North Atlantic Volcanic Province, may help to decipher the early stages of rifting and spreading of the area.

\section{METHOD}

The 520 samples investigated were taken from 118 flows, 7 dikes, and 12 volcaniclastic units. On the ship, samples were drilled perpendicular to the core axis after a fiducial mark for the vertical orientation was drawn. In the laboratory, samples were measured for remanent magnetization on a Digico spinner magnetometer and for susceptibility on a sensitive low field $1-\mathrm{kHz}$ susceptibility bridge. All specimens were further remeasured after AF-demagnetization in peak fields of up to $100 \mathrm{mT}$. From these data median destructive fields (MDF) and stable inclinations were determined. Thermal demagnetization was performed for 12 samples at temperatures up to $690^{\circ} \mathrm{C}$, to evaluate secondary components of NRM.

\section{RESULTS}

The magnetic results are summarized in Figure 2, showing stable inclination, MDF variation, NRM, susceptibility, and Q ratio as mean values with error bars for each unit investigated. 


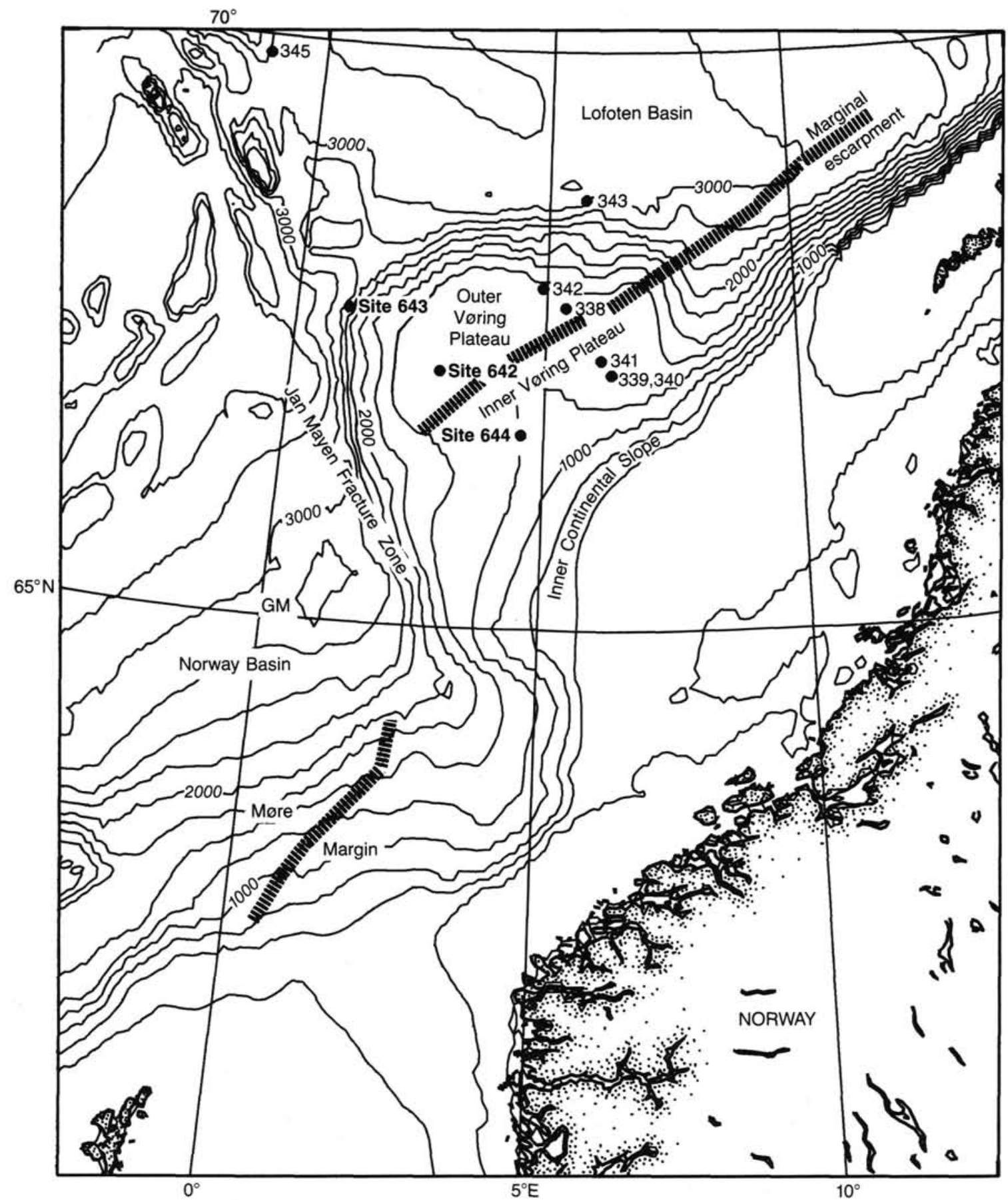

Figure 1. Location of ODP Leg 104 Sites 642, 643, and 644 on the Vøring Plateau in the Norwegian Sea. Contour interval, $250 \mathrm{~m}$.

The strongest variation in all the properties (except the $\mathrm{Q}$ ratio) occurs at the boundary between the upper and lower series at about $1100 \mathrm{~m}$.

This boundary was magnetically recognized by a drop of about two orders of magnitude of both NRM and susceptibility. The contrast between the volcanic series is confirmed by the present study. MDF and stable inclination unit mean values below the boundary exhibit considerably larger standard deviations. In Figure 3 stable inclination, NRM, and Q-values across the boundary are shown on a larger scale. Below volcaniclastic unit S43, the inclination record is highly irregular with two small zones of normal inclinations at about 1115 and 1190 mbsf, respectively. With the exception of dike unit D5, NRM values beneath unit $\mathrm{S} 43$ are less than $0.12 \mathrm{~A} / \mathrm{m}$.

The larger scatter of low-amplitude remanence and susceptibility values for the lower series cannot be explained by larger measurement errors in connection with the lower amplitudes of remanence and susceptibility, as all magnitudes were well above the noise level of the instruments involved.

From careful examination of demagnetization curves (both thermal and AF) it is obvious that the nature of multicomponent magnetization is different between the upper and lower series. In Figure 4 examples of demagnetization behavior throughout the volcanic section are given using Zijderveld plots and ste- 


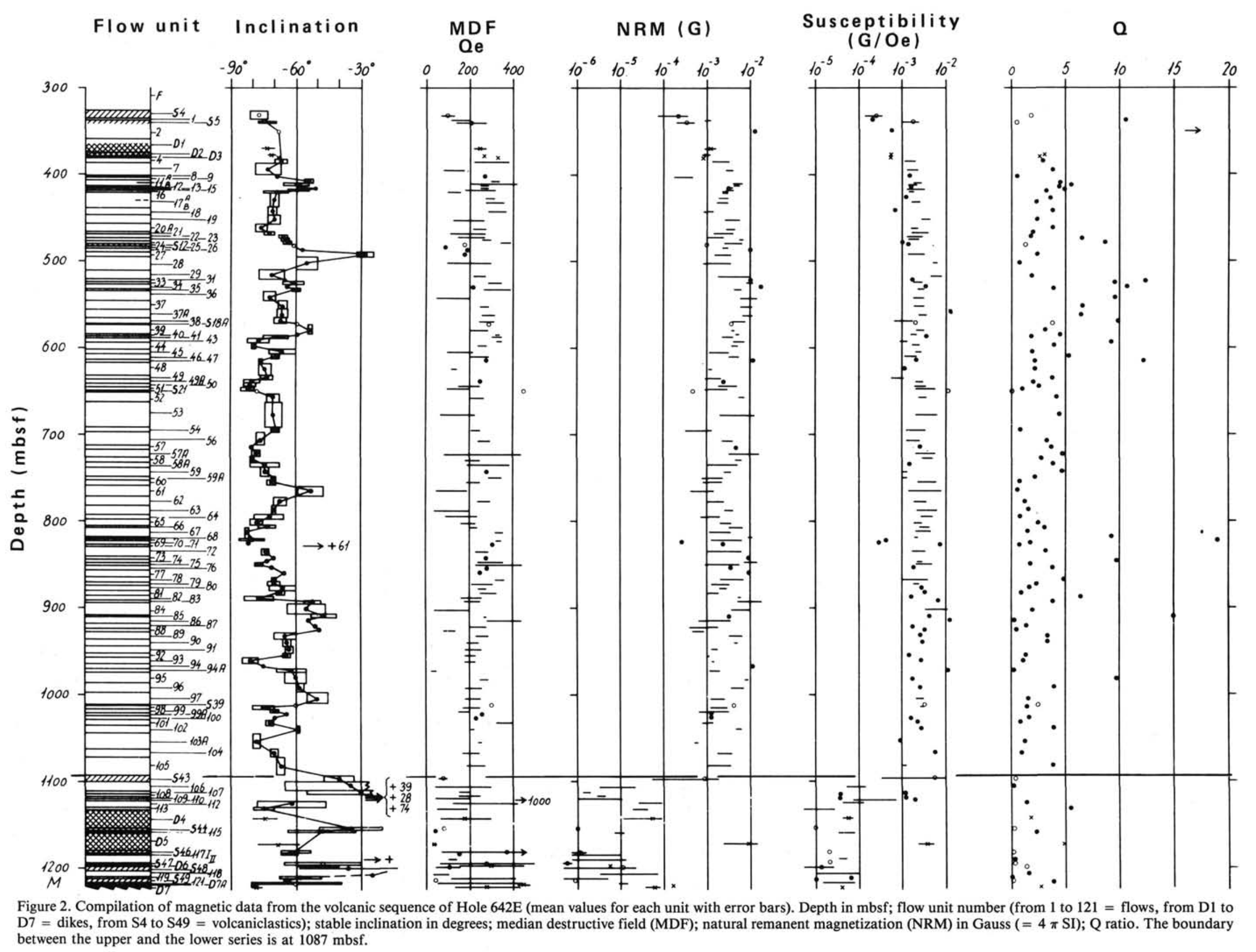




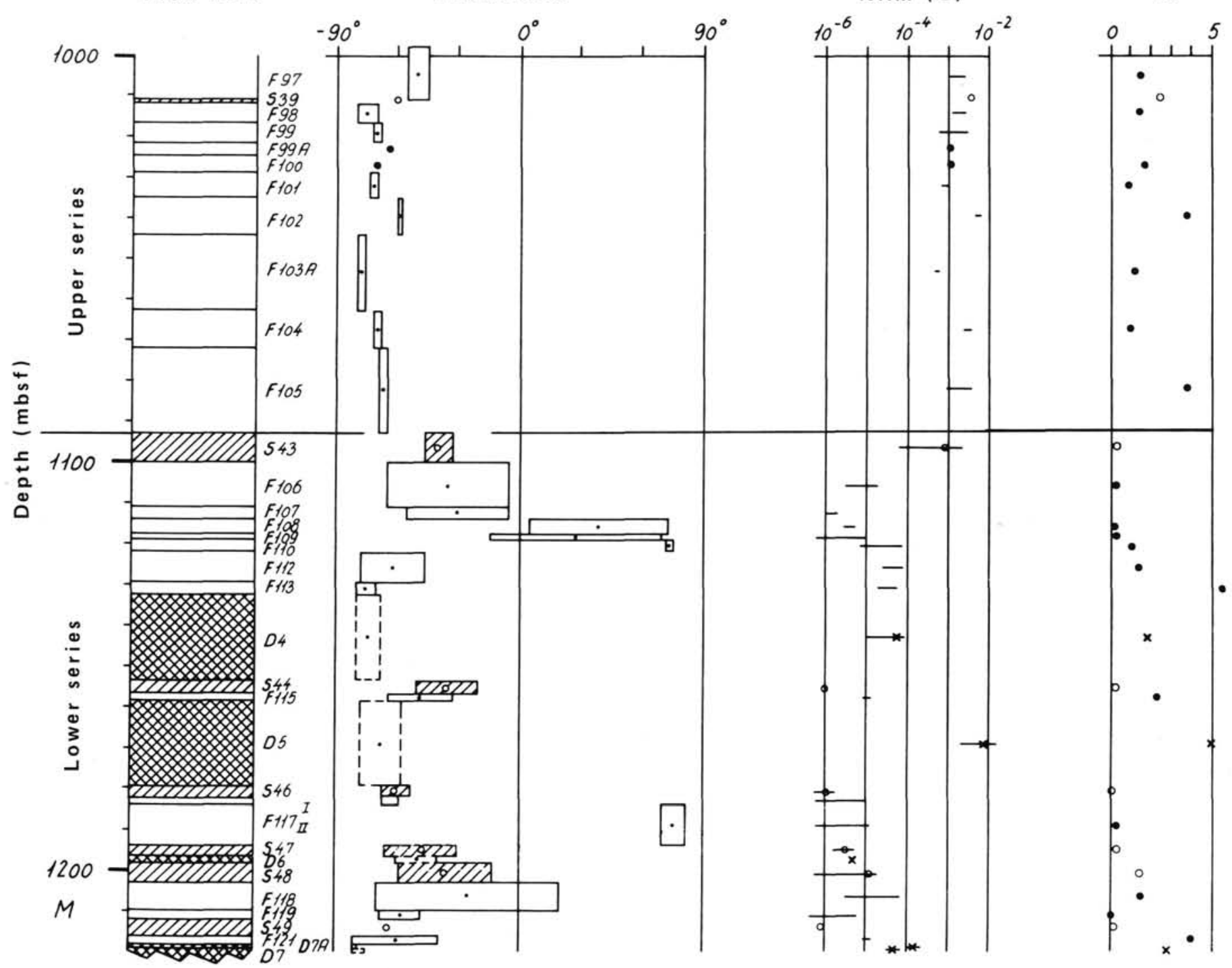

Figure 3. Stable inclination, NRM, and Q ratio for the lower volcanic series of Hole 642E (enlarged from Fig. 2).

reographic projections of remanence directions. Within the upper series, and for dike D5 of the lower series, two directions are typical: a stable reverse direction and a normal direction that is typically demagnetized in AF peak fields of less than $10 \mathrm{mT}$. For thermal demagnetization, temperatures of less than $300^{\circ} \mathrm{C}$ are sufficient to destroy the normal NRM component in the upper series.

No stable end values could be found for more than $50 \%$ of the samples in the lower series. The series is dominated by the two dikes, D4 and D5, which both have reverse polarities. From magnetic characteristics, D5 resembles the dikes and massive flows of the upper series, whereas D4 has a much lower NRM and a thermal demagnetization pattern that suggests $95 \%$ of its NRM is of viscous origin (Fig. 4). From petrological and geochemical investigations (Eldholm, Thiede, Taylor, et al., 1987), the nature of D4 as a dike is now questioned. It has geochemical affinities to the flows of the lower series, and may be a thick flow. Our interpretation, however, is that it is either a dike or sill which intruded into the lower series before the formation of the upper series. The two normal-polarity zones are $15 \mathrm{~m}$ and $6 \mathrm{~m}$ from the upper and lower contacts of the two dikes, respectively (Fig. 3), and the reverse field flows and volcaniclastics between exhibit shallower inclinations than the dikes. Shallower reverse inclinations occur also for units S44 and F115, sandwiched between the two dikes. From these observations we argue that the lavas between the present normal zones may have been originally normally magnetized until the intrusion of dike D4. This dike possibly fed a flow within the uppermost part of the lower series, and D5 fed a flow in the upper series. Although the thickness of the dikes is not known, evidence from grain-size distributions as well as from magnetic characteristics indicates a width of a few meters. Dikes of this size may be a sufficient heat source to activate water within adjacent sediments and to cause alteration and introduce secondary stable magnetization. For example, from highly altered basalts in eastern Iceland Schönharting and Ghisler (1982) reported that remagnetization can affect different parts of flows in highly variable ways and that it can completely mask primary magnetizations. The multicomponent NRM with strongly varying inclination values within the flows and volcaniclastics around dikes D4 and D5 supports the case for remagnetization.

With this assumption we arrive at a normal polarity interval in the lower series of between 1113 and 1194 mbsf. This interval may in fact reach deeper, as the presence of dikes D6 and D7 
may also indicate overprinting of the flows and volcaniclastics in their vicinity. The top of the lower series, units F106, F107, and S43, is also probably reversed, and may be related to dike D4.

Two possible zones of normal polarity were found in the upper series from shipboard measurements. The first of these is now discarded on the basis of AF demagnetization pattern and explained by incorrect up-down marking of the core piece (Unit S5, Core 5, Section 3). The other zone (unit F71 only) may have a similar explanation and is also discarded.

An attempt was made to analyze the multicomponent NRM of the upper and lower series using the method of Stupavsky and Symons (1978). AF demagnetization data of 45 samples were found to be reasonably consistent for which up to three vectors of NRM were determined. This analysis showed, however, that two of these with reversed polarities were almost identical in direction (a few degrees difference only). Thus only two NRM vectors were used in the final analysis. As declination values were arbitrary for all samples, the azimuthal distribution of resulting vectors should display no preferred direction. An example for the normal component distribution is given in Figure $5 \mathrm{~A}$. As the normal component, in almost all cases, is that with the least coercive force, it may be assumed to be of viscous origin and acquired during the present Brunhes chron. The relatively strong inclination scatter (Fig. 5A) is interpreted as the effect of the calculation using noisy data. Consequently the declination of the normal component was set to zero and we were able to calibrate the declination directions of the reversed component for each sample (Fig. 5B). With the exception of two samples, all reversed directions plot in the southern hemisphere. The mean values are $-65.8^{\circ}$ for inclination and $175.2^{\circ}$ for declination with $\mathrm{k}$ values and $\alpha_{95}$ values of 16 and $5.6^{\circ}$, respectively.

\section{Magnetic Polarity and Age}

A main objective of this study was to clarify the polarity record at Site 642 and to provide a record of stable inclination values to help in correlating the Vøring Plateau dipping basalts with the others of the early Tertiary North Atlantic Volcanic Province. The upper volcanic series of Hole 642E is of reversed polarity and the lower series is normal between 1113 and 1194 mbsf and possibly reversed above and below this interval.

Constraints on the mininum age of the reversed upper series may be obtained using marine magnetic anomalies (Hagevang et al., 1983). Site 642 is situated immediately landward of anomaly 24B (Eldholm, Thiede, Taylor, et al., 1987). Assuming that at least part of the magnetic source of anomaly 24B is represented by normally magnetized dipping basalts below anomaly $24 \mathrm{~B}$, we can arrive at an age corresponding to polarity chron $24 \mathrm{r}$ or older for the reversed upper series at Site 642 . The validity of this constraint is strongly dependent on the assumption that the dipping basalts in a section from Site 642 seaward to the first encounter of anomaly 24B become progressively younger. This progression appears to be the case judging from the more or less continuous seaward thickening of the dipping reflector sequence in seismic sections of this area (Eldholm, Thiede, Taylor, et al., 1987). Therefore a mininum age for the upper series at Site 642 can be proposed within polarity chron $24 \mathrm{r}$.

There are two reasons that this age may be the correct age for the upper series. First, the proximity of Site 642 to marine magnetic anomaly 24B (chron 24.2) does not leave much space to accommodate dipping basalts of chrons $24 \mathrm{r}$ and 25 in between, allowing an age within chron $25 \mathrm{r}$ for the upper series. Second, middle Eocene and late early Eocene paleontologic ages were reported for the upper and lower series, respectively (Eldholm, Thiede, Taylor, et al., 1987). The apparent discrepancies between the magnetically and paleontologically derived ages would be further increased by assigning the upper series an age older than chron $24 r$.
Consequently, the normal polarity zone within the lower series of Hole $642 \mathrm{E}$ may be related to polarity chron 25 , placing the lower series into the Paleocene with an age at the top of the normal polarity zone of $55.8 \mathrm{Ma}$ using the magnetic polarity time scale of Harland et al. (1982) and of Berggren et al. (1985). But Tarling (1983) assigns this boundary an age of $54 \mathrm{Ma}$. The younger ages indicated by the fossil record may perhaps be due to paleontologic contamination of the core from overlying sediments. From paleomagnetic considerations alone the interpretation of the normal polarity zone of the lower series to be of chron 25 age is rather ambiguous and may be a minimum estimate.

It is of great interest to compare the ages interpreted for the upper and lower series of Site 642 with those from other areas of the North Atlantic Volcanic Province. The upper part of the lower basalt series of the Faeroes, which is petrologically and geochemically similar to the upper series of Site 642 , has been correlated by Smythe et al. (1983) with chron 25, while Abrahamsen et al. (1984) correlate the upper series with chron 24.2 and the deeper part of the lower basalt series with chron 24r. For the almost exclusively reverse polarities of the basalts from the Rockall Plateau (Roberts et al., 1984) and from east Greenland (Larsen and Watts, 1985), ages corresponding to chron $24 \mathrm{r}$ were interpreted. We agree with the interpretation by Roberts et al. (1984), who placed the first phase of voluminous effusive volcanism (the dipping reflectors) of the North Atlantic Volcanic Province entirely within chron 24 r.

\section{Inclination Variation and Growth Rate of Lava Pile}

The stable inclination record of Hole 642E (Fig. 2) records an almost cyclical downhole variation. A total of up to 20 cycles is observed. If one interprets these cycles as secular variations of the Earth's magnetic field and assumes an average length of one cycle to be on the order of $1,000 \mathrm{yr}$, the total period for building the lavas of the upper series would be about 10 to 100 k.y. Such rapid growth rate exceeds rates from other areas by a factor of 10 to 100 . In Iceland, for example, growth rates were found to range from $0.7 \mathrm{~km} / \mathrm{m}$.y. to about $4 \mathrm{~km} / \mathrm{m}$.y. for the late Tertiary plateau basalts (summarized in Abrahamsen et al., 1984). A more conservative, but still very high growth rate estimate can be obtained with a model that allows for intermittent lava production, separated by larger periods of quiescence. A detailed comparison between the inclination record and petrological composite record (Eldholm, Thiede, Taylor, et al., 1987) shows some correlation of inclination cycles with petrological properties that can be interpreted in terms of intermittent volcanic activity. Detailed rock magnetic studies are needed to pursue this issue further. At this stage, a very rapid lava production for the upper series is strongly indicated.

Cyclical variations of stable inclination have also been noted for the basalts drilled from the Rockall Plateau (Krumsiek and Roberts, 1984). A strong similarity for the uppermost 200 to 300 $\mathrm{m}$ could be indicative of similar high growth rates.

\section{Inclination and Paleolatitude}

To calculate the mean inclination, inclination statistics of Kono (1980) were applied. A mean value of $-67.5^{\circ}$ lies fairly close to the mean value of $-65.8^{\circ}$ calculated from the analysis after Stupavsky and Symons (1978). The paleolatitudes were calculated by assuming the mean field to be an axial dipole field.

Apparent paleolatitudes vs. present latitudes for the North Atlantic Volcanic Province are shown in Figure 6. Mean values for west Greenland (Deutsch and Kristjansson 1974, Sharma and Athavale 1975), east Greenland (Faller 1975, Faller and Soper 1979, Tarling 1967, Tarling and Otulana 1972, Hailwood 1977), Faeroe Islands (Tarling 1970, Abrahamsen et al., 1984), British Isles (Irving 1964, Tarling, 1970) and Rockall Bank 
F1

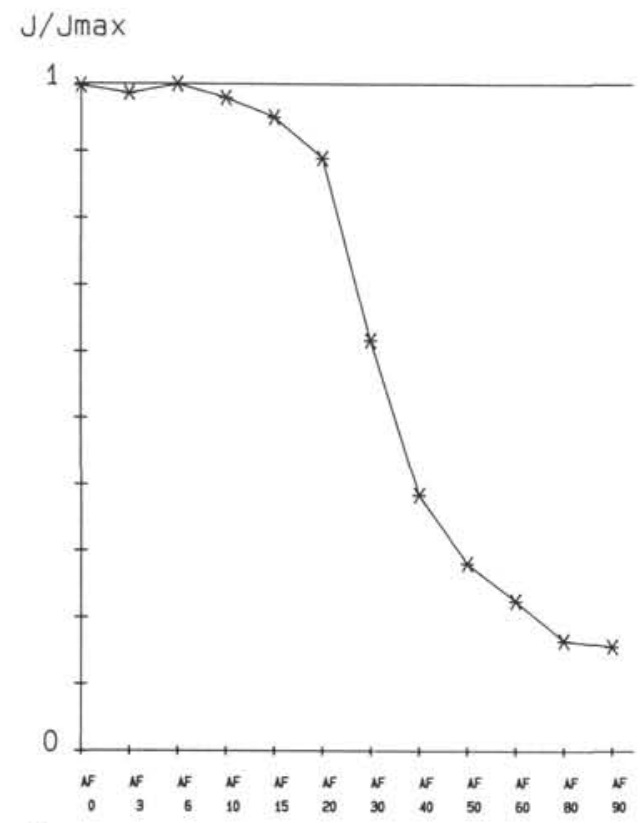

A

Treatment

F25

J/Jmax

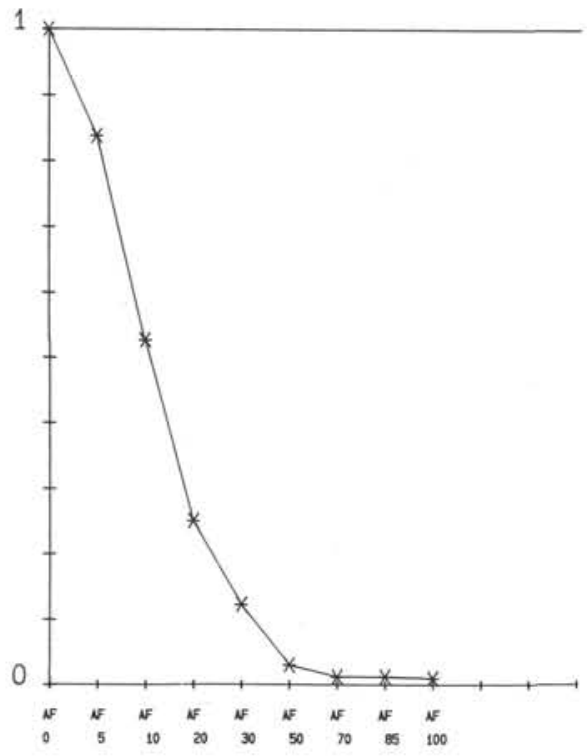

Treatment

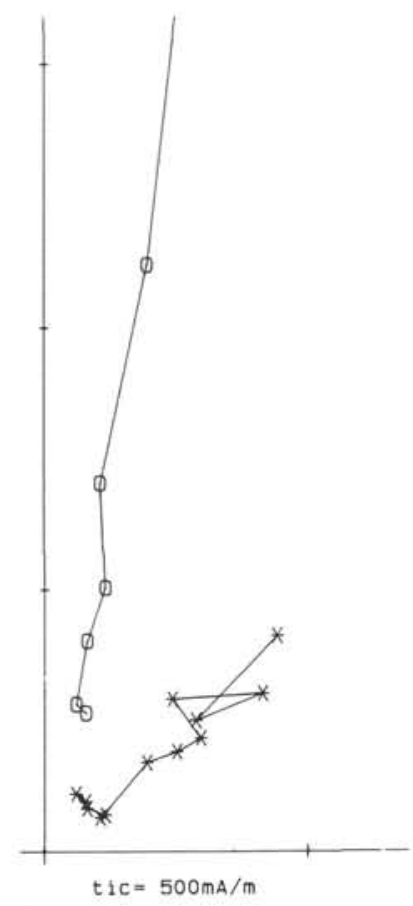

B

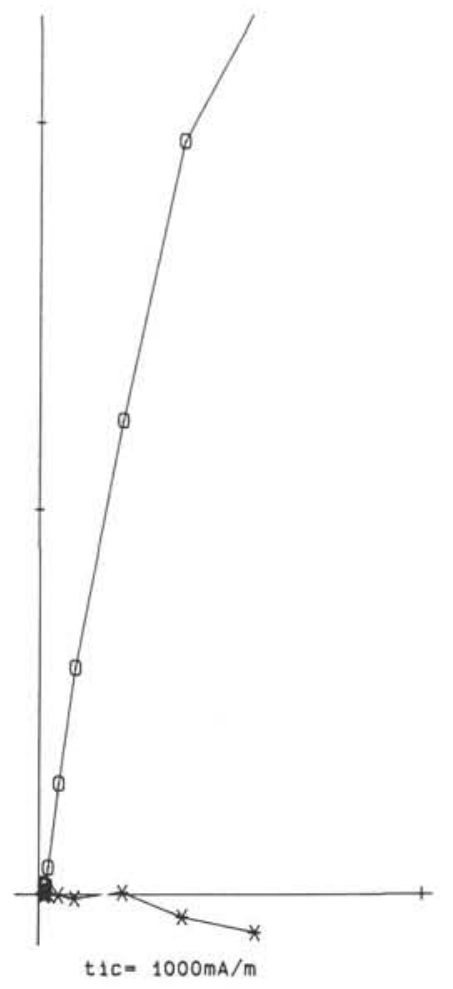

B

B
N

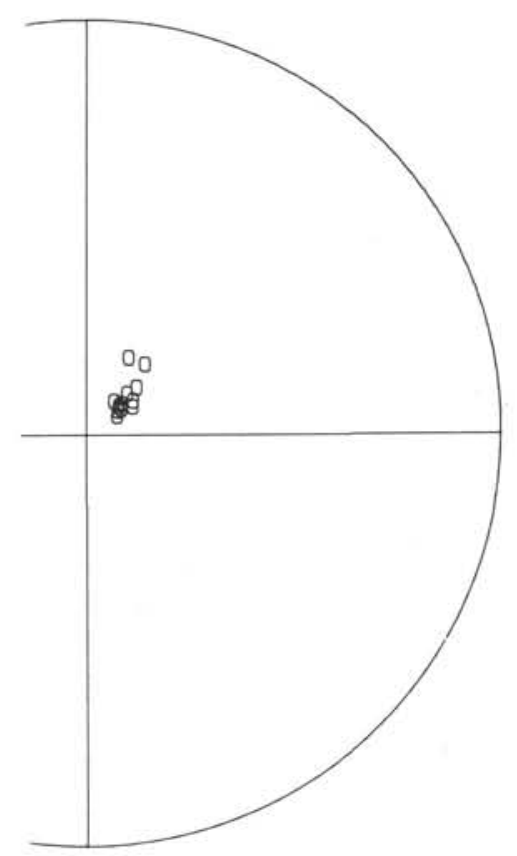

C

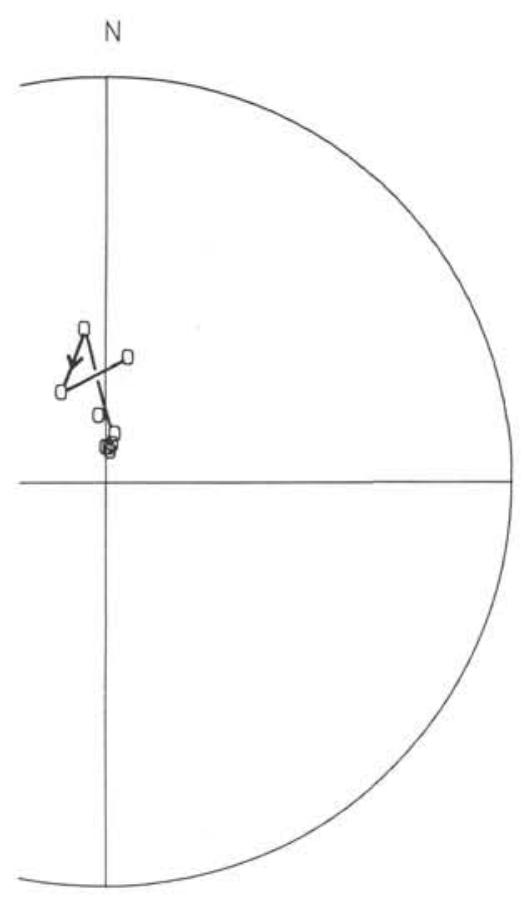

C

\section{A}

Figure 4. Typical examples of AF- and thermal demagnetization results for flow units F1, F25, and F94, for dike unit D4, and for volcaniclastic unit S44: F1 (Sample 104-642E-16R-1, 131-133 cm). F25 (Sample 104-642E-23R-3, 69-91 cm). F94 (Sample 104-642E-60R-2, 46-46 cm). D4 (Sample 104642E-100R-2, 26-26 cm). S44 (Sample 104-642E-102R-1, 46-49 cm). (A) Normalized remanence vs. AF-treatment (mT) or thermal treatment $\left({ }^{\circ} \mathrm{C}\right.$ ). (B) Zijderveld plots. (C) Stereographic projections. 
F94

$J / J \max$

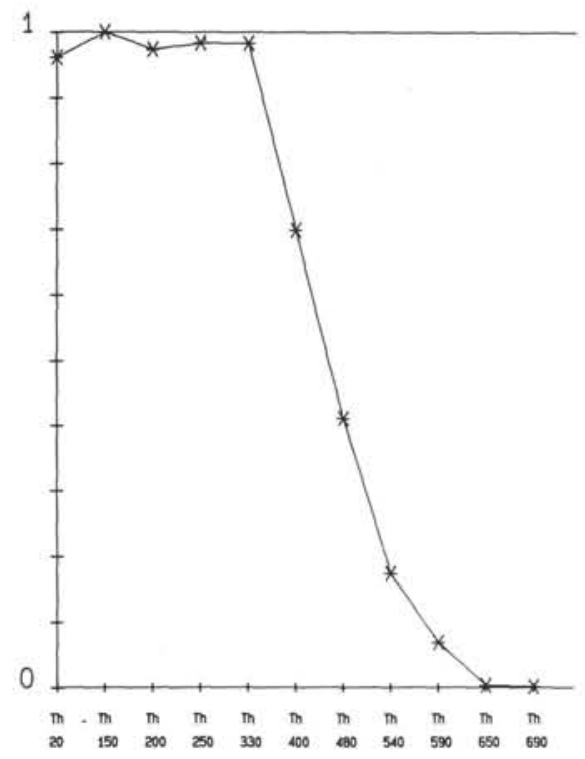

A Treatment

\section{D4}

$J / J \max$

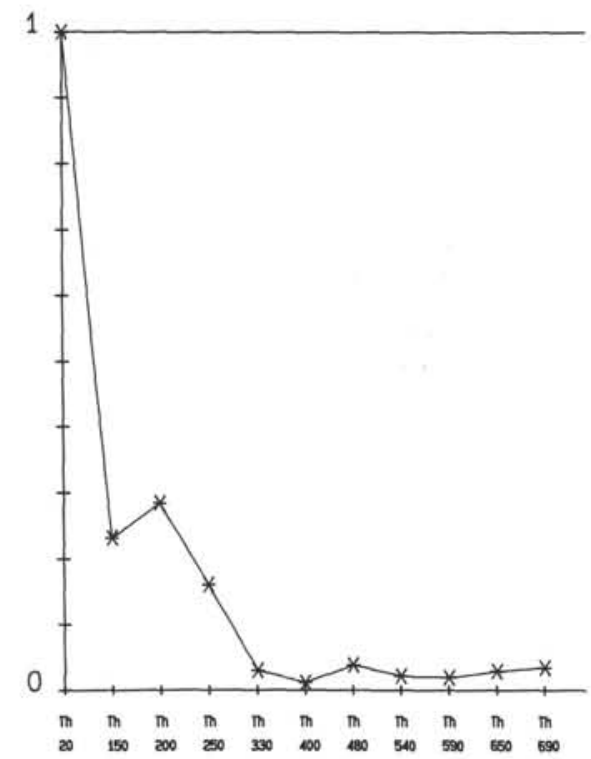

A Treatment
N, Up

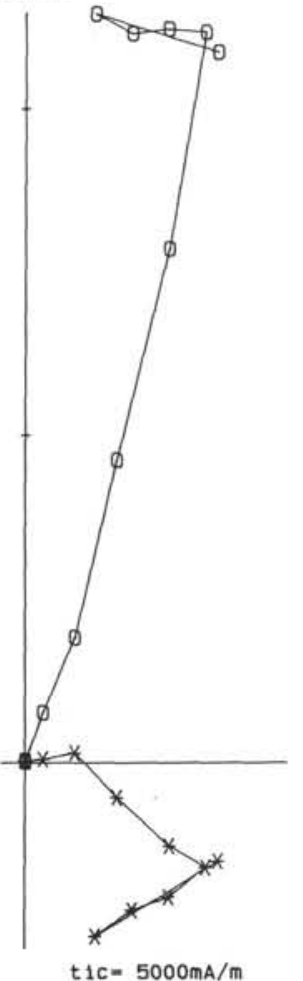

B

N, Up

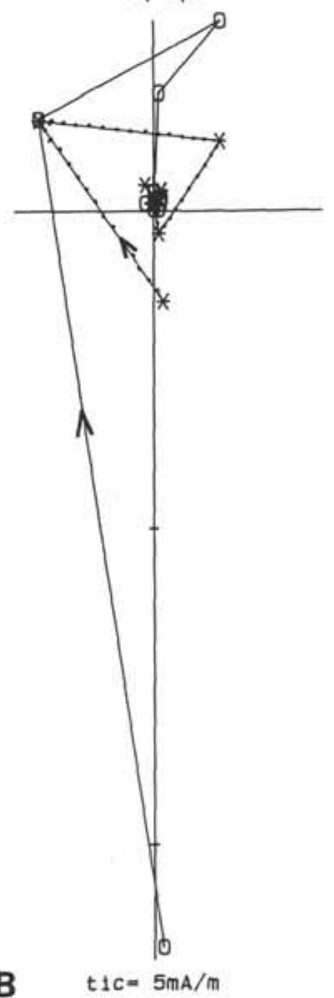

C
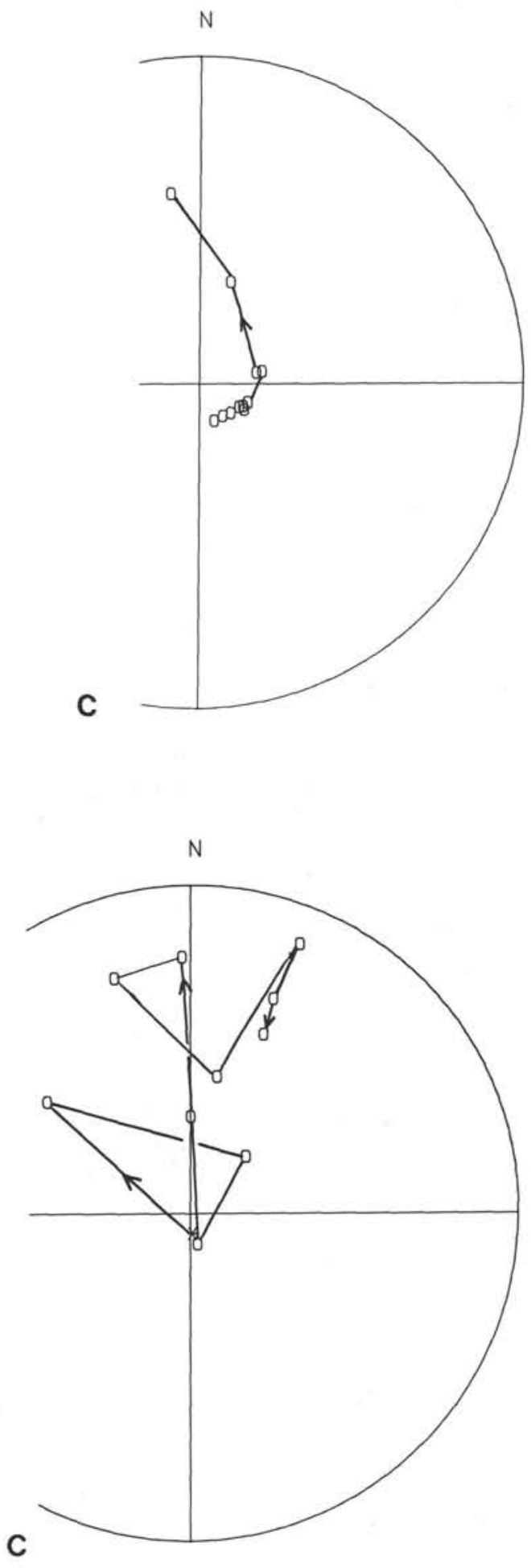

Figure 4 (continued). 


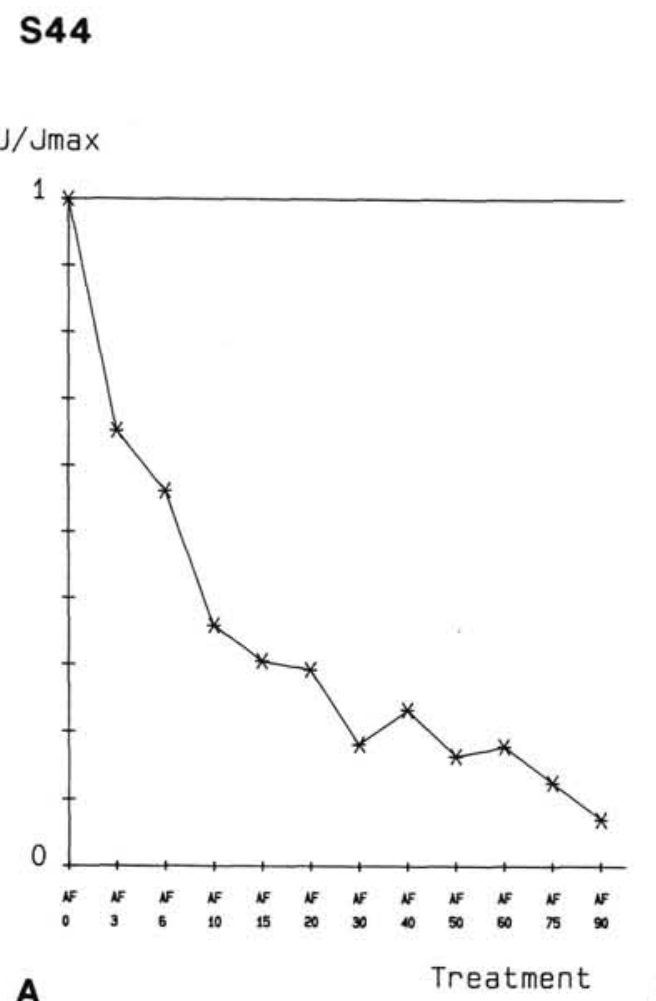

$$
\text { W, Up }
$$

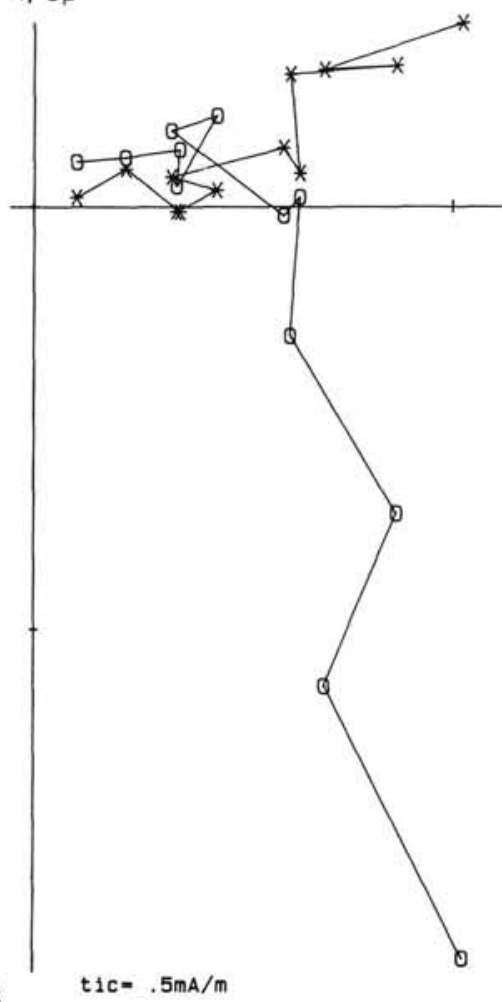

Figure 4 (continued).
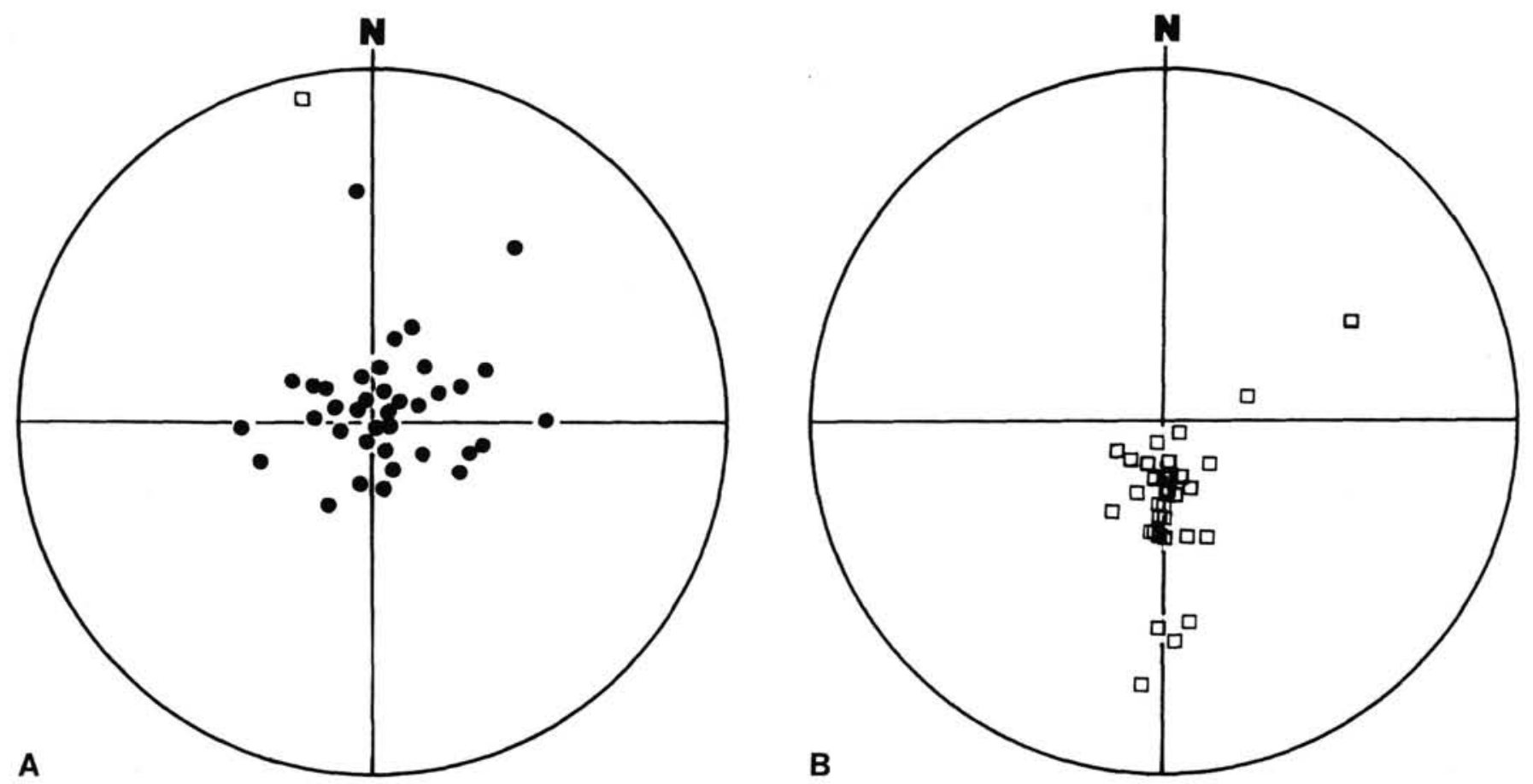

Figure 5. Stereographic projection of stable directions from vector analysis of AF-demagnetization (Stupavsky and Symons, 1967). (A) Normal components, (B) reverse components, assuming that the normal component for each sample has zero declination.

(Krumsiek and Roberts 1984) are included. A distinct pattern emerges with all areas displaying paleolatitudes lower by 12 to $20^{\circ}$ compared to their present latitude. The diagonal in Figure 6 separates farsided from nearsided virtual geomagnetic poles. The farsidedness of the poles for the North Atlantic Volcanic
Province cannot be explained by magnetic refraction effects or by minor but systematic dipole offsets as described by Hailwood (1977). It is difficult to visualize large deviations of the geomagnetic field from an axial field over time spans of the order 1 m.y. (Wilson, 1971). We interpret the differences between 


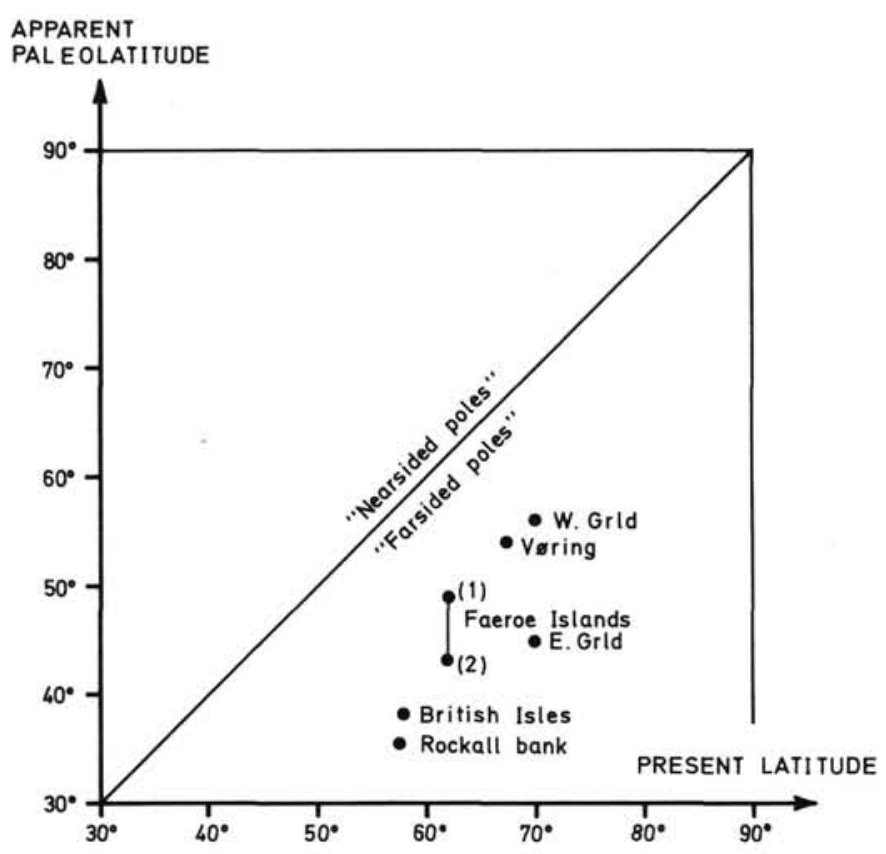

Figure 6. Apparent paleolatitude vs. present latitude for the North Atlantic Volcanic Province. W. Grld = west Greenland (Deutsch and Kristjansson, 1974; Sharma and Athavale, 1975). E. Grld = east Greenland (Faller, 1975; Faller and Soper, 1979; Tarling, 1967; Tarling and Otulana, 1972; Hailwood, 1977). Vøring = present study. Faeroe Islands (1. Tarling, 1970; 2. Abrahamsen et al., 1984). Rockall Bank (Krumsiek and Roberts, 1984). (1) Tarling (1970); (2) Abrahamsen et al. (1984).

apparent paleolatitudes and present latitudes as a northward component of movement of the two lithospheric plates. The average movement amounted to $15^{\circ} \pm 5^{\circ}$ in the last $55 \mathrm{~m}$.y., corresponding to an average velocity of $33 \mathrm{~mm} / \mathrm{yr}$. This interpretation agrees with that for the Faeroes (Abrahamsen et al., 1984). In both cases, a Tertiary northward movement is superimposed on E-W spreading having comparable magnitudes.

\section{CONCLUSIONS}

The upper volcanic series of Hole $642 \mathrm{E}$ is found to be reversed throughout and was correlated with chron $24 \mathrm{r}$. For the lower series the polarity distribution is fairly complex due to widespread remagnetization effects. A normal polarity zone is interpreted between 1113 and 1194 mbsf and was tentatively correlated with chron 25 .

From cyclic variation patterns of the downhole stable inclination record a rapid growth rate of the upper series is inferred, exceeding growth rates of, for example, the late Tertiary Icelandic Plateau basalts by an order of magnitude. Further rock magnetic studies and detailed comparison with petrological results are warranted to substantiate this difference.

Polarity and age assignments for the upper series at Site 642, Vøring Plateau, compare well with the Rockall Plateau, the Faeroes, and East Greenland, and substantiate that the rifting stage of the North Atlantic opening was related to a surge of voluminous volcanic activity, causing the formation of tholeiitic dipping basalts within a fairly short time span, entirely within chron $24 \mathrm{r}$ of the magnetic polarity time scale (Berggren et al., 1985).

Paleolatitude for the Vøring Plateau upper volcanic series is about $15^{\circ}$ more southerly than its present latitude and falls well within the range of paleolatitude determined for other areas of the North Atlantic Volcanic Province.

\section{ACKNOWLEDGMENTS}

We thank the shipboard scientists who supported this study, particularly paleomagnetist $\mathrm{U}$. Bleil and the group of petrologists who allowed the magnetic measurements to be performed on their sample sets. Their cooperation is greatly acknowledged in view of the extra work required during sampling and marking of the samples with respect to top and bottom. We also thank the reviewers of this paper, J. Hall and D. Tarling, for helpful comments and suggestions. S. Lauge Petersen measured the majority of samples and the Danish Science Research Council supported this study by grant J. Nr. 11-4084.

\section{REFERENCES}

Abrahamsen, N., Schönharting, G., and Heinesen, M., 1984. Paleomagnetism of the Vestmanna core and magnetic age and evolution of the Faeroe lslands. In Berthelsen, O., Noe-Nygaard, A., and Rasmussen, J. (Eds.), The deep drilling project 1980?-1981 in the Faeroe 1slands. Ann. Soc. Sci. Faeroe., Suppl. IX, 93-108.

Berggren, W. A., Kent, D. V., and Flynn, J. J., 1985. Paleogene geochronology and chronostratigraphy. In Snelling, N. J. (Ed.), Geochronology and the geological record. Geol. Soc. London, Spec. Pap., 141-188.

Deutsch, E. R., and Kristjansson, L. G., 1974. Paleomagnetism of late Cretaceous-Tertiary volcanics from Disko Island, west Greenland. Geophys. J. R. Astron. Soc., 39:343-380.

Eldholm, O., Thiede, J., Taylor, E., and Shipboard Scientific Party, 1987. Summary and preliminary conclusions, ODP Leg 104. In Eldholm, O., Thiede, J., Taylor, E., et al., 1987, Proc. ODP., Init. Repts., 104: College Station, TX (Ocean Drilling Program), 751771.

Eldholm, O., Thiede, J., Taylor, E., et al., 1987. Proc. ODP, Init. Repts., 104: College Station, TX (Ocean Drilling Program).

Faller, A. M., 1975. Paleomagnetism of the oldest Tertiary basalts in the Kangerdlugssuaq area of east Greenland. Bull. Geol. Soc. Den., 24: 173-178.

Faller, A. M., and Soper, N. J., 1979. Paleomagnetic evidence for the origin of the coastal flexure and dyke swarm in central east Greenland. J. Geol. Soc. London, 138:737-744.

Hagevang, E. A., Eldholm, O., and Aalstad, I., 1983. Pre-23 magnetic anomalies between Jan Mayen and Greenland-Senja fracture zones in the Norwegian Sea. Mar. Geophys. Res., 5:345-384.

Hailwood, E. A., 1977. Configuration of the geomagnetic field in early Tertiary times. J. Geol. Soc. London, 133:23-38.

Harland, W. B., Cox, A. V., Llewellyn, P. G., Pickton, C. A. G., Smith, A. G., and Walters, R., 1982. A Geological Time Scale: Cambridge (Cambridge University Press).

Irving, E., 1984. Paleomagnetism and Its Application to Geological and Geophysical Problems: New York (Wiley).

Kono, M., 1980. Statistics of paleomagnetic inclination data. J. Geophys. Res., 85:3878-3882.

Krumsiek, K., and Roberts, D. G., 1984. Paleomagnetics of Tertiary sediments from the southwest Rockall Plateau, Deep Sea Drilling Project Leg 81. In Roberts, D. G., Schnitker, D., et al., Init. Repts. DSDP, 81: Washington (U.S. Govt. Printing Office), 837-851.

Larsen, L. M., and Watt, W. S., 1985. Episodic volcanism during breakup of the North Atlantic: evidence from the east Greenland plateau basalts. Earth Planet. Sci. Lett., 73:105-116.

Roberts, D. G., Backman, J., Morton, A. C., Murray, J. W., and Keene, J. B., 1984. Evolution of volcanic rifted margins: synthesis of Leg 81 results on the west margin of Rockall Plateau. In Roberts, D. G., Schnitker, D., et al., Init. Repts. DSDP, 81: Washington (U.S. Govt. Printing Office), 883-911.

Schönharting, G., and Ghisler, M., 1982. Zones of polarity reversal of stable remanent magnetization within some basaltic flows of the Iceland Research Drilling Project core. J. Geophys. Res., 87:65916600.

Sharma, P. V., and Athavale, R. N., 1975. Paleomagnetic evidence relating to the Cenozoic drift of Greenland. Tectonophysics, 29:209221.

Smythe, D. K., Chalmers, J. A., Skuce, A. G., Dobinson. A., and Mould, A. S., 1983. Early opening history of the North Atlantic-I. Structure and origin of the Faroe-Shetland Escarpment. Geophys. J. R. Astron. Soc., 72:373-398. 
Stupavsky, M., and Symons, D. T. A., 1978. Separation of magnetic components from $\mathrm{AF}$ step demagnetization data by least squares computer methods. J. Geophys. Res. 83:4925-4932.

Tarling, D. H., 1967. The Palaeomagnetic properties of some Tertiary lavas from east Greenland. Earth Planet. Sci. Lett., 3:81-88.

Tarling, D. H., 1970. Paleomagnetic results from the Faroe Islands. In S. K. Runcorn (Ed.), Paleogeophysics: London (Academic Press), 193-208.

Tarling, D. H., and Otulana, H. I., 1972. The paleomagnetism of some Tertiary igneous rocks from Ubekendt Island, west Greenland. Bull. Geol. Soc. Den., 21:395-406.
Tarling, D. H., 1983. Paleomagnetism principles and applications in geology. Geophysics and Archaeology: London (Chapman and Hall). Wilson, R. L., 1971. Dipole offset-the time average paleomagnetic field over the past 25 million years. Geophys. J. R. Astron. Soc., 22:491504.

Date of initial receipt: 10 March 1987

Date of acceptance: 16 March 1988

Ms 104B-179 